\section{CLÍNICA AO PÉ DA LETRA}

\author{
A neurose obsessiva no divã de \\ Lacan, de Charles Melman. Rio de \\ Janeiro: Imago/Tempo Freudiano, 2011, \\ $470 \mathrm{p}$.
}

\section{Francisco Leonel F. Fernandes}

Psicanalista, membro do Tempo Freudiano Associação Psicanalítica, e professor da Universidade Federal Fluminense.

A porta de entrada do livro de Charles Melman é a clínica psicanalítica, na medida em que esta deve ser orientada por uma leitura, como condição de sua transmissão. Resulta da organização de seu seminário sobre a neurose obsessiva nos anos de 1987 a 1989. A indicação no título, "no divã de Lacan", é signo de seu retorno à clínica de Lacan, pois, como sabemos, os casos princeps de Lacan foram os próprios casos clínicos de Freud aqui, o caso conhecido como Homem dos Ratos de 1909.

O percurso do livro, fiel ao decurso do seminário, inicia por situar o conceito lacaniano de discurso, a partir da emissão radiofônica (Radiofonia) na qual Lacan resumiu sua teoria dos quatros discursos. É daí que parte Melman, buscando situar o essencial da neurose, em particular a neurose obsessiva, na relação do sujeito ao Outro organizada como discurso. Discurso do Outro - para sermos precisos -, no qual se demarca a posição do sujeito em vista de seu modo de gozo, seu sintoma e sua fantasia.

Em seguida, Melman nos convida a nos exercermos em uma leitura, rente à letra de Freud, do texto do "Homem dos Ratos" - como orientava Lacan. O autor trata de escandir o texto de Freud valendose, justamente, das chaves de leitura que Lacan nos legou. Nesse percurso, o que vai se traçando é a lógica própria que comanda a organização subjetiva da neurose obsessiva, e num movimento de passagem do local ao global, a constituição do falante nas leis da linguagem como desejo.

O que está em jogo é a transmissão da psicanálise a partir da clínica. O desafio de, mais do que dar a saber, nos surpreender no plano de um ensino, com os modos como a lógica do obsessivo opera e faz valer seus desígnios no contexto transferencial da cura. Para, a partir desse viés, investigar quais são os termos estruturais nos quais a psicanálise se organiza como prática e discurso, enfim, como uma práxis justa também para outras estruturas clínicas nas quais o que opera é a palavra e o significante. Por isso, essa disciplina a que ele nos convida desde o início do seminário: a de partir seguindo à letra o texto de Freud conforme Lacan preconizava.

Seguir à letra um texto, só pode acontecer se situamos este texto em posição Outra, interrogante, por relação ao que já sabemos dele. E sob certo limite; aquele 
que é posto, justamente, pela disciplina de se submeter à sua letra. O que um texto nos autoriza a tirar dele não pode ser qualquer coisa, há um limite às invectivas possíveis. Porém, se isto que nele põe limites não pode se positivar, é pelo retorno ao texto que podemos estar abertos ao que nele (sua identidade fixada de algum modo em sua escritura), mais do que fechamento é direção.

Decorre daí Melman nos propor ler na contramão das estipulações conceituais que fornecem um entendimento das estruturas clínicas, neuroses, perversões e psicoses em torno de uma visada de sistema, apoiada em consensos consagrados. Uma vez que este procedimento, tão comum na literatura, frequentemente desemboca numa espécie de escolástica, de produção de saber, que visa estabelecer um acordo, sob as figuras de uma nosografia fechada, embora sofisticada. Tal expediente trunca mais do que deixa passar a transmissão da psicanálise quando esta vem se apoiar no que se pode dizer a respeito das estruturas clínicas. Como periga acontecer quando uma exposição de caso clínico se anule em sua efetividade, muito difícil e delicada de ser alcançada, justamente por se colocar a serviço de um saber que, por sua função na estrutura, visa precisamente desconhecer e abolir o que é próprio do registro do real inerente à prática clínica da psicanálise. Em manobras que, apesar de todo tipo de advertência, vemos disseminar-se extensivamente no campo lacaniano ele próprio. Não é justamente isso que se reproduz quando se repete à exaustão que o neurótico recalca, ou que o psicótico forclui o nome do pai?

Quando Melman retoma a exposição de Freud ele isola nela a estrutura local na qual se suporta a clínica analítica - a associação livre. É aí que ele articula um limite que marca o materialismo da psica- nálise. Isto é, é no campo aberto pela associação livre, a manifestação mais concreta do que, no plano conceitual, poderíamos designar como cadeia significante, é aí que se localiza a topologia decisiva para a organização do falante enquanto subjetividade e desejo. É em torno da associação livre, da cadeia, que esses termos, postos por Lacan - o sujeito, o Outro, o objeto a encontram-se articulados como estrutura e em função. Vemos então perfilarem-se nas anotações do próprio texto de Freud sobre a fala do paciente, as várias nuances do significante, cuja lógica se especifica frequentemente em termos muito gerais, a partir do tratamento do Homem dos Ratos. Quais sejam: o caráter paradoxal do significante, que no obsessivo degenera na dúvida e na instauração de uma lógica binária que oblitera a possibilidade de ato; a faceta injuntiva do significante, que no obsessivo degenera em compulsão; a denegação constitutiva do sujeito, que no obsessivo decai na figura neutra de um sujeito fora do desejo, um sujeito genérico, "livre" de responder a partir daquilo que o marca, e muitas outras nuances que o contexto dessa resenha não permite resumir são, enfim, diferenciadas e discutidas pelo autor. E, além disso, a questão objetal, tal como esta pode se evidenciar, já em Freud. Observa-se então que se a questão objetal do sujeito gira, no plano do sintoma, em função de uma economia do dom, da analidade, no entanto, é do lado do olhar que a questão fundamental de sua fantasia e de sua relação com a dívida se organizou.

Nessa via, Melman chega a isolar de modo nunca igualado antes, a articulação estrutural que especifica a neurose obsessiva: a retenção, em nível da cadeia significante — isolável nas associações, no modo como o sujeito toma a palavra daquilo que, uma vez perdido, faz a or- 
dem do discurso circular: o objeto a. Dito assim, soa abstrato, mas, após o percurso do seminário, podemos divisar a gravidade da posição obsessiva — a de obliterar discursivamente a ordem discurso ela mesma, neutralizando-a como campo onde o que é mais radicalmente implicado pelo significante, tudo o que deriva do registro pulsional, deve, ou deveria se desdobrar.

No percurso, é a clinica lacaniana que brota, que ressurge com certo frescor, como que renovada. E isso desde pequenos detalhes, de indicações aparentemente à margem, mas absolutamente pertinentes e estimulantes para o prático em seu dia a dia - com as patologias obsessivas que aparecem constantemente com designações diversas de bulimia, toxicomanias, etc. - até indicações mais amplas, a respeito de como o horror do obsessivo à subjetividade, ao desejo, contamina a cultura, determinando muitos dos efeitos que hoje associamos à contemporaneidade. E indicações sobre como a lógica do dom, numa estranha aliança com a economia, decaiu numa incansável rotina de se tentar compor os laços sociais a partir de arranjos paritários protocolares. Arranjos que vão se propor a ordenar desde a vida dos casais, até a educação dos filhos e mesmo uma generalização, através do aparelho judiciário, de uma equalização que finalmente instalaria a justa medida nas relações entre os homens. Do mesmo modo, o leitor encontrará no livro observações preciosas sobre a fixação, no discurso comum, de uma lógica injuntiva ao consumo que opera uma forçagem no sentido de colapsar a diferença entre desejo e demanda através da anulação do registro da temporalidade - campo onde o sujeito se desdobra como evanescência e corte no tempo - impedindo que esta última se renove; numa lógica que delimita e fixa o circuito pulsional à mercadoria. Melman faz em suma um longo percurso que situa nossa dependência, enquanto falantes, das leis da linguagem, e o modo como estabelecemos a questão objetal a partir de suas operações, dando lugar, ou, ao contrário, anulando o campo do discurso. E isso, a partir do âmbito local da prática clínica.

Recebida em 23/6/2011.

Aprovada em 15/8/2011.

Francisco Leonel F. Fernandes

francisco.lf@mac.com

VALE A PENA QUEIMAR A PSICANÁLISE?

O livro negro da psicanálise. Viver e pensar melhor sem Freud, organizado por Catherine Meyer. Edição brasileira com organização e prefácio de Simone Perelson e tradução de Maria Beatriz de Medina e Simone Perelson. Rio de Janeiro: Civilização Brasileira, 2011. $638 \mathrm{p}$.

Joel Birman

Psicanalista. Professor titular do Instituto de Psicologia da UFRJ; professor adjunto do Instituto de Medicina Social da Uerj.

\section{Um livro-acontecimento}

O livro negro da psicanálise é um livro-acontecimento, como foi denominado pelo dossiê organizado pela revista Le Nouvel Observateur, publicada após o lançamento da obra na França, em 2005. Isso porque foi o disparador de numerosas polêmicas, as quais incidiram não apenas no campo psicanalítico, mas também na representação social da psicanálise. Lido vorazmente, em 